\title{
Parkinson's Disease: Mechanisms, Pathogenesis, Animal Models and Tests
}

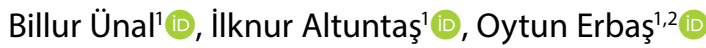

Parkinson's disease (PD) was first described as "tremor paralysis" by James Parkinson in 1817. ${ }^{[1]}$ Motor symptoms occur as dopamine (DA) levels are depleted around $70-80 \%$ in advanced ages. ${ }^{[2]}$ It is a degenerative process that affects other brainstem pigmented neurons, especially the substantia nigra (SN) in the basal ganglia. The main clinical symptoms are bradykinesia, rigidity, resting tremor, and postural reflex disorder. It occurs with the degeneration and/or loss of cells that secrete dopamine as a result of damage in the substantia nigra region of the brain. ${ }^{[3,4]}$ As the disease progresses and dopamine in the brain decreases, the symptoms of PD become more pronounced.

Symptoms such as tremor, difficulty in walking, and other problems related to movement arise in the patients. ${ }^{[5]}$ Neuropathological factors of Parkinson's disease; vascular diseases, previous brain infections, some medications, atherosclerosis, familial causes, trauma, poisoning, toxins, tumors, and consequently loss of neurons and neurotransmitters. ${ }^{[3,4]}$ Researchers are working on ways to stop or slow the loss of these dopamine-producing cells. There

'ERBAS Institute of Experimental Medicine, Illinois, USA \& Gebze, Turkey 2Department of Physiology, Medical Faculty of Demiroğlu Bilim University, Istanbul, Turkey

Correspondence: Billur Ünal. Deneysel Tıp Enstitüsü, 41470 Gebze-Kocaeli, Türkiye.

E-mail: billurunal0@gmail.com

Cite this article as: Ünal B, Altuntaş I, Erbaş O. Parkinson's Disease: Mechanisms, Pathogenesis, Animal Models and Tests. JEB Med Sci 2020;1(3):135-139.

doi: $10.5606 /$ jebms.2020.75629

Received : September 14, 2020

Accepted : November 18, 2020

Published online : December 29, 2020

@2020 Journal of Experimental and Basic Medical Sciences. All rights reserved.

\begin{abstract}
Parkinsonism is a progressive brain disorder characterized by tremor, rigidity, bradykinesia, akinesia, and loss of postural reflexes. The pathologic feature of Parkinson's disease, basically known as a movement disorder, is the progressive loss of dopaminergic neurons in the substantia nigra pars compacta, one of the main components of basal ganglia, and accumulation of alpha-synuclein called intracellular protein aggregates (Lewy bodies) in surviving neurons. There are several reasons for the disease, among which genetic factors and various toxins are noted. Parkinson's disease is the second most common neurodegenerative disease in the world and in our country that occurs in association with advanced age with the increase in life expectancy. In this review, the formation mechanism of the disease, Parkinson's tests, and methods used in experimental modeling will be discussed.

Keywords: Animal models, Parkinson's disease, parkinsonism.
\end{abstract}

is currently no cure for PD but medications can help control the symptoms. ${ }^{[5]}$

\section{Mitochondrial dysfunction}

Mitochondria are an intracellular powerhouse that performs important cellular reactions, including energy production, calcium metabolism and regulation of cell death. ${ }^{[6]}$

The direct link between mitochondrial dysfunction and Parkinson's disease was established in 1983 as a result of the discovery of 1-methyl4-phenyl-1,2,5,6-tetrahydropyridine (MPTP), a neurotoxic that elicits symptoms of PD in drugexposed patients, and later MPTP neurotoxicity is validated in the primate model..$^{[7]}$

Evidence of mitochondrial dysfunction is obtained from brain samples of PD patients ${ }^{[8]}$ Among the main features of mitochondrial dysfunction are symptoms such as excessive ROS (reactive oxygen species) production, ATP depletion, mitochondrial 
DNA (mtDNA) deletion, caspase release, and disruption of electron transport complex (ETC) ${ }^{[9]}$ It is known that mitochondrial complex I activity is significantly decreased in substantia nigra of patients and mtDNA deletion is observed at high levels. $^{[8,10]}$

ROS production causes damage to the activity of mitochondrial complex I (NADH dehydrogenaseubiquinone oxidoreductase) and III (ubiquinonecytochrome c oxidoreductase), inducing oxidation of proteins in the mitochondria and cytoplasm, leading to mitochondrial dysfunction. ${ }^{[1]}$

\section{Oxidative stress in Parkinson's disease}

Another pathological process of PD is oxidative stress. The shift in the balance between oxidants and antioxidants in favor of oxidants is termed "oxidative stress".[12] Oxidative stress, which is a pathological process that occurs during the formation and excretion of free radicals that may cause neurodegeneration, is responsible for the pathogenesis of many diseases such as cancer, diabetes, cardiovascular and neurological diseases, atherosclerosis, and inflammatory disorders. ${ }^{[12,13]}$

Free radicals are divided into reactive oxygen (ROS) and nitrogen (RNS) species. With the help of antioxidants, and repair systems ROS/RNS are removed from the body and the organism is protected from oxidative stress. ${ }^{[14]}$ Brain cells are very sensitive for ROS production because it uses $20 \%$ of the oxygen in the blood. ${ }^{[15]}$ The antioxidant that protects the brain from oxidative stress is glutathione (GSH). ${ }^{[16,17]}$

Oxidative stress is one of the pathogenic mechanisms of dopaminergic cell death in substantia nigra in Parkinson's disease. ${ }^{[6]}$ As a result of increased oxidative stress, the ubiquitinproteasomal system (UPS) is over-activated, resulting in the accumulation of damaged and/or misfolded proteins. ${ }^{[11]}$

Other findings for mitochondrial dysfunction related to oxidative stress and dopamine cell damage include mutations in the genes of proteins such as a-syn (alpha-synuclein), parkin (PARK), DJ-1 (daisuke-junko-1), or PINK (PTEN-induced kinase). It is also associated with familial forms of Parkinson's disease. ${ }^{[18]}$ Parkin and PINK1 are localized in the mitochondria and are closely related to the normal functioning of the mitochondria. Parkin mutation impairs mitochondrial complex-1 activity.
Free oxygen radical release increases. Also, functional disorders caused by PINK1 mutation lead to increased oxidative stress. Mutations or decreased expression of related proteins result in mitochondrial degradation, oxidative stress, and protein aggregation. Moreover, reactive dopamine quinones formed by dopamine oxidation cause ROS levels to rise, leading to oxidative stress. Increased oxidative stress affects cell survival by disrupting the internal balances of the wrongly modified or damaged proteins of the UPS (ubiquitin-proteasomal system). ${ }^{[19]}$ Environmental toxins cause oxidative stress by increasing mitochondrial dysfunction and free radical formation. Mitochondrial dysfunction caused by complex I inhibition leads to an increase in oxidative stress and a decrease in ATP production and results in cell death by causing damage to intracellular components. Additionally, neuro-inflammatory mechanisms contribute to the process that leads to oxidative stress. In summary, these various cellular mechanisms attributed to oxidative stress are involved in the selective degeneration of dopaminergic neurons. PD also occurs as a result of the degeneration of dopaminergic neurons. ${ }^{[18]}$

\section{EXPERIMENTAL ANIMAL MODELS AND TESTS IN PARKINSON'S DISEASE}

\section{Non-transgenic models of PD}

In non-transgenic models, neurodegeneration occurs in a short time and there is no accumulation in Lewy bodies. It is aimed to develop the most appropriate models to investigate the degenerative process developing in dopaminergic neurons in the substantia nigra and to try symptomatic treatments. ${ }^{[20]}$

\section{A) Parkinson Model induced by 6-Hydroxydopamine (6-OHDA)}

6-OHDA (6-hydroxydopamine) is a specific catecholaminergic neurotoxin used to produce lesions in nigrostriatal dopamine neurons in rats. It is used to reveal the Parkinson model in rodents. ${ }^{[20]}$

It cannot cross the blood-brain barrier, therefore it should be injected directly into the pars compact or striatum in substantia nigra. 6-OHDA should be preferred as a one-sided model. Because the bilateral injection of this compound into the striatum causes severe adipsia (absence of thirst), aphagia (refusal or inability to swallow), seizures, and it often leads to death. ${ }^{[21]}$ 


\section{B) Parkinson Model induced by 1-methyl 4-phenyl 1,2,3,6-tetrahydropyridine (MPTP)}

MPTP is an artificial drug that was unexpectedly obtained by a chemist producing drugs in a laboratory in California, the USA in the early 1980s while trying to create a drug called 1-methyl-4-phenyl-4propionoxypiperidine (MPPP). It was observed that a group of people using MPTP developed a syndrome that was irreversible and very similar to Parkinson's disease. ${ }^{[22]}$ MPTP itself is not toxic. It can cross the blood-brain barrier and cause PD rapidly when it is injected.

After MPTP enters the brain, it is metabolized by the monoamine oxidase $B$ (MAO-B) enzyme of astrocytes into the toxic cation 1-methyl-4phenylpyridinium (MPP +). MPP+ kills dopamineproducing neurons in the pars compacta of substantia nigra. It is transported to dopaminergic neurons in the substantia nigra pars compacta by the dopamine transporter and blocks mitochondrial complex I activity. Thus, mice to which this model is applied develop motor disorders that can be detected by behavioral tests. ${ }^{[23]}$

\section{C) Paraquat and Maneb-Induced Parkinson Model}

Paraquat is the structural analog of MPP + and is a widely used pesticide in the world. It can cross the brain-blood barrier. Thus, it enters the structure of neurons and blocks complex I in their mitochondria. One of the advantages of using the paraquat model is that it creates Lewy body-like inclusions containing alpha-synuclein. However, these models give conflicting and variable results in terms of behavior and dopaminergic cell death. ${ }^{[24,25]}$

\section{D) Rotenone-Induced Parkinson Model}

Rotenone is a naturally occurring organic compound and has been used as a broad spectrum insecticide and pesticide. It is a potent inhibitor of complex I in ETC. Mitochondrial dysfunction, which develops as a result of rotenone application, is to disrupt all defense systems of dopaminergic cells against oxidative damage and cause degeneration. Because of these effects, it has been used to develop in vivo rodent models of PD. ${ }^{[26]}$

Rotenone is lipophilic like MPTP and can cross the blood-brain barrier. A negative aspect of this model is that it causes too much death in laboratory animals and it leads to variable dopaminergic damage. ${ }^{[20]}$

\section{Transgenic Models of PD}

\section{A) Alpha-Synuclein (a-synuclein)}

Alpha-synuclein, generally found in brain regions (brainstem and cerebral cortex) thought to cause neurodegenerative diseases, is formed as a result of abnormal folds in proteins. It is a neuronal protein encoded by the SNCA gene and the main neuropathological feature of PD.

The general name of the diseases caused by the accumulation of these bodies is called "Lewy Body Dementia (LBD)". All Lewy body diseases show the accumulation of alpha-synuclein protein and resulting in neuronal cell deaths in neuropathology. When looking at the physical effects of alphasynuclein, increased cellular oxidative stress damage and inflammation are observed. ${ }^{[27,28]}$

\section{B) Leucine-Rich Repeat Serine/Threonine Kinase 2 (LRRK2)}

LRRK 2 mutations are the most common cause of Parkinson's disease in autosomal dominant inheritance. Overexpression of LRRK2 as wild type in bacterial artificial chromosome (BAC-bacterial artificial chromosome) transgenic mice leads to increased dopamine release in the striatum and hence motor hyperactivity.

Overexpression of the G2019S mutated protein results in an age-dependent decrease in striatal content. It is thought that LRRK2 has a role in dopaminergic transmission by causing a decrease in dopamine uptake and release. ${ }^{[29]}$

\section{C) PTEN-Induced Putative Kinase 1 (PINK1)}

PINK1 is the second most common mutation. This gene is responsible for $4 \%$ of early-onset Parkinson cases. ${ }^{[30]}$ If disturbances occur at the mitochondrial level and neurotransmission, there is no change in the number of dopaminergic neurons and striatal dopamine levels. ${ }^{[29]}$

\section{D) Parkin}

Parkin mutations are the most common cause of autosomal recessive PD. Parkin, encoded by the PARKN gene, is a ubiquitin E3 ligase. It directly participates in mitochondria quality control with PINK1. ${ }^{[20]}$

\section{E) Mito-Park}

It is a model based on the lack of oxidative phosphorylation that occurs as a result of a disruption in mitochondrial DNA. ${ }^{[31]}$ 


\section{TESTS}

\section{1) Rotarod}

In this test, the mouse is first placed on the rotarod properly. Thus, the mouse will be constantly in motion to stay upright and standing. The falling speed of the mouse is controlled. It is the most preferred test in PD. ${ }^{[32]}$

\section{2) Adhesive Tape Test}

It is applied to evaluate the asymmetry caused by nigrostriatal damage. The hind legs of the rats are glued with adhesive tape. The playing times with the tape are noted in 15 minutes. ${ }^{\text {[3] }}$

\section{3) Open Field Test}

There are a slowdown and decrease in the movements of the animal with Parkinson's. The behavior of rats in a square or rectangular box of equal length is observed. The floor is divided into compartments. The animals' displacement between compartments, vertical sniffing, first movement time after being released to the center, and the number of defecations are noted and evaluated. ${ }^{[34]}$

\section{4) Cylinder Test}

In the unilateral Parkinson's disease model, usage of the contralateral forelimbs is reduced. The test is performed to evaluate the usage of the asymmetrical limbs. Rats are placed in cylinders and are observed for five minutes. ${ }^{[33]}$

\section{5) Apomorphine Test}

Apomorphine is a non-selective dopamine receptor agonist and shows its effect in the striatum through postsynaptic dopaminergic receptors. The test is used for grading the contralateral rotation movement of the brain induced by apomorphine, striatal lesion, and treatment success. The animals are placed in a box with an open-top and dark-colored.

Animals are placed in the box following the administration of subcutaneous injection of $1 \mathrm{mg} / \mathrm{kg}$ apomorphine and observed for 40 minutes.

For apomorphine-induced locomotor activity test, total distance traveled and average velocities between 15 and 20 minutes are analyzed. For apomorphine-induced rotation test, animals are left in the box following injection. It is counted each $10^{\text {th }}$, $20^{\text {th }}$, and 30th minutes for how many times they turn around for 3 minutes. Rotating around itself and completing 360 degrees is considered as 1 rotation, other turns are not counted. ${ }^{[35,36]}$

\section{DISCUSSION AND CONCLUSION}

As a consequence of the literature review, it is understood that Parkinson's disease is a neurodegenerative disease seen in the elderly. It occurs as a result of the progressive loss of dopaminergic neurons in the pars compacta of the substantia nigra of the brain. One of the pathological processes of PD is oxidative stress. Oxidative stress occurs as a result of impairment of mitochondrial function. Mitochondrial dysfunction results in the damage of components within the cell and many pathways that cause cell death. Findings enable us to create experimental animal models with the neurodegenerative process. Thus, the degenerative process that takes place in dopaminergic neurons was investigated and many suitable models were created. One of the experimental animal models, MPTP continues to be the best model for investigating PD. Presently there is no cure for PD; the goal of tests is to detect, prevent, manage, or treat this disease in the early stage.

\section{Declaration of conflicting interests}

The authors declared no conflicts of interest with respect to the authorship and/or publication of this article.

\section{Funding}

The authors received no financial support for the research and/or authorship of this article.

\section{REFERENCES}

1. Calne DB. Parkinson's disease is not one disease. Parkinsonism Relat Disord 2000;7:3-7.

2. Van Laar VS, Berman SB. Mitochondrial dynamics in Parkinson's disease. Exp Neurol 2009;218:247-56.

3. de Lau LM, Breteler MM. Epidemiology of Parkinson's disease. Lancet Neurol 2006;5:525-35.

4. Grażyńska A, Urbaś W, Antoniuk S, Adamczewska K, Bień M, Chmiela T, et al. Comparative analysis of nonmotor symptoms in patients with Parkinson's Disease and atypical parkinsonisms. Clin Neurol Neurosurg 2020;197:106088.

5. Wendy H. How Does Dopamine Affect Parkinson's Disease. 2018. p. 2-22.

6. Moon HE, Paek SH. Mitochondrial dysfunction in Parkinson's disease. Exp Neurobiol 2015;24:103-16.

7. Langston JW, Ballard P, Tetrud JW, Irwin I. Chronic Parkinsonism in humans due to a product of meperidineanalog synthesis. Science 1983;219:979-80.

8. Bender A, Krishnan KJ, Morris CM, Taylor GA, Reeve AK, Perry $\mathrm{RH}$, et al. High levels of mitochondrial DNA deletions in substantia nigra neurons in aging and Parkinson disease. Nat Genet 2006;38:515-7.

9. Exner N, Lutz AK, Haass C, Winklhofer KF. Mitochondrial dysfunction in Parkinson's disease: molecular 
mechanisms and pathophysiological consequences. EMBO J 2012;31:3038-62.

10. Rouaud T, Corbillé AG, Leclair-Visonneau $L$, de Guilhem de Lataillade A, Lionnet A, Preterre $C$, et al. Pathophysiology of Parkinson's disease: Mitochondria, alpha-synuclein and much more.... Rev Neurol (Paris) 2020:S0035-3787(20)30676-7.

11. Abou-Sleiman PM, Muqit MM, Wood NW. Expanding insights of mitochondrial dysfunction in Parkinson's disease. Nat Rev Neurosci 2006;7:207-19.

12. Cooke MS, Lunec J, Evans MD. Progress in the analysis of urinary oxidative DNA damage. Free Radic Biol Med 2002;33:1601-14.

13. Halliwell B, Gutteridge JM. Free radicals in biology and medicine. Croydon: Oxford University Press; 2015.

14. Semchuk KM, Love EJ, Lee RG. Parkinson's disease: a test of the multifactorial etiologic hypothesis. Neurology 1993;43:1173-80.

15. Berk M, Kapczinski F, Andreazza AC, Dean OM, Giorlando $\mathrm{F}$, Maes $\mathrm{M}$, et al. Pathways underlying neuroprogression in bipolar disorder: focus on inflammation, oxidative stress and neurotrophic factors. Neurosci Biobehav Rev 2011;35:804-17.

16. Steckert AV, Valvassori SS, Moretti M, DalPizzol F, Quevedo J. Role of oxidative stress in the pathophysiology of bipolar disorder. Neurochem Res 2010;35:1295-301.

17. Hemmati-Dinarvand $M$, Saedi $S$, Valilo $M$, KalantaryCharvadeh A, Alizadeh Sani M, Kargar R, et al. Oxidative stress and Parkinson's disease: conflict of oxidantantioxidant systems. Neurosci Lett 2019;709:134296.

18. Blesa J, Trigo-Damas I, Quiroga-Varela A, Jackson-Lewis VR. Oxidative stress and Parkinson's disease. Front Neuroanat 2015;9:91.

19. Akbayır $E$, Şen $M, A y U$, Şenyer $S$, Tüzün $E$, Küçükali $C i$. Parkinson hastalığının etyopatogenezi. Deneysel Tıp Dergisi 2017;7:1-23.

20. Gubellini P, Kachidian P. Animal models of Parkinson's disease: An updated overview. Rev Neurol (Paris) 2015;171:750-61.

21. Jackson-Lewis V, Blesa J, Przedborski S. Animal models of Parkinson's disease. Parkinsonism Relat Disord 2012;18 Suppl 1:S183-5.

22. Akbulut H, Köylüoğlu $E$, Erbaş O . 1-metil-4-fenil-1,2,3,6tetrahidropiridinin (MPTP) Parkinson hastalığı üzerindeki etkileri. İstanbul Bilim Üniversitesi Florence Nightingale Tıp Dergisi 2019;5:48-54.

23. Javitch, JA, D'Amato, RJ, Strittmatter, SM, Snyder, SH.
Parkinsonizmi indükleyen nörotoksin, N-metil-4fenil-1, 2, 3, 6-tetrahidropiridin: N-metil-4-fenilpiridin metabolitinin dopamin nöronları tarafından alınması seçici toksisiteyi açıklar. Ulusal Bilimler Akademisi Bildirileri 1985;82:2173-7.

24. Wakabayashi K, Tanji K, Odagiri S, Miki Y, Mori F, Takahashi H. The Lewy body in Parkinson's disease and related neurodegenerative disorders. Mol Neurobiol 2013;47:495-508.

25. Bove C, Coleman FH, Travagli RA. Characterization of the Basic Membrane Properties of Neurons of the Rat Dorsal Motor Nucleus of the Vagus in Paraquat-Induced Models of Parkinsonism. Neuroscience 2019;418:122-32.

26. Kang SY, Lee SB, Kim HJ, Kim HT, Yang HO, Jang W. Autophagic modulation by rosuvastatin prevents rotenone-induced neurotoxicity in an in vitro model of Parkinson's disease. Neurosci Lett 2017;642:20-6.

27. Creed RB, Goldberg MS. New Developments in Genetic rat models of Parkinson's Disease. Mov Disord 2018;33:717-29.

28. Sohal RS, Orr WC. The redox stress hypothesis of aging. Free Radic Biol Med 2012;52:539-55.

29. Blandini F, Armentero MT. Animal models of Parkinson's disease. FEBS J 2012;279:1156-66.

30. Kurman Y. Parkinson Hastalığı ve İlişkili Olduğu Genler. DÜBITED 2018;6:231-9.

31. Pickrell AM, Pinto $M$, Moraes CT. Mouse models of Parkinson's disease associated with mitochondrial dysfunction. Mol Cell Neurosci 2013;55:87-94.

32. Shiotsuki $H$, Yoshimi $K$, Shimo Y, Funayama M, Takamatsu $\mathrm{Y}$, Ikeda $\mathrm{K}$, et al. A rotarod test for evaluation of motor skill learning. J Neurosci Methods 2010;189:180-5.

33. Sughrue ME, Mocco J, Komotar RJ, Mehra A, D'Ambrosio $A L$, Grobelny BT, et al. An improved test of neurological dysfunction following transient focal cerebral ischemia in rats. J Neurosci Methods 2006;151:83-9.

34. Blizard DA, Wada Y, Onuki Y, Kato K, Mori T, Taniuchi T, et al. Use of a standard strain for external calibration in behavioral phenotyping. Behav Genet 2005;35:323-32.

35. Campbell JC, Jeyamohan SB, De La Cruz P, Chen N, Shin $D$, Pilitsis JG. Place conditioning to apomorphine in rat models of Parkinson's disease: differences by dose and side-effect expression. Behav Brain Res 2014;275:114-9.

36. Mutluay SU. Bazal Ganglia ve Hipokampuse Unilateral Aav Aracılı Alfa-Sinükleinin Enjeksiyonu ile Oluşturulan Parkinson Hastalığı Modelinin Davranışsal ve Patolojik Olarak Değerlendirilmesi. Farmakoloji Programı [Yüksek Lisans Tezi], Ankara: Hacettepe Üniversitesi; 2017. 